NBER WORKING PAPER SERIES

\title{
EFFECTS OF REGULATION ON UTILITY FINANCING : THEORY AND EVIDENCE
}

\author{
Robert A. Taggart, Jr • \\ Working Paper No. 866
}

\section{NATIONAL BUREAU OF ECONOMIC RESEARCH 1050 Massachusetts Avenue Cambridge MA 02138}

March 1982

J.L. Kellogg Graduate School of Management, Northwestern University. I am grateful to Suk Heun Yoon for able research assistance and to the National Science Foundation for financial support under Grant No. SOC 77-07251. The research reported here is part of the NBER's research program in Financial Markets and Monetary Economics. Any opinions expressed are those of the author and not those of the National Bureau of Economic Research. 


\section{Effects of Regulation on Utility Financing: \\ Theory and Evidence}

\section{ABSTRACT}

This paper examines the financing decisions of regulated public utilities. It is argued that the regulatory process affects utility financing choices both by conditioning the environment in which these choices are made and by creating opportunities for firms to influence the regulated price through strategic financing behavior. The nature of this regulatory effect continually changes, however, as economic conditions change and as regulators, firms and consumers adapt to one another's decisions. The direction of the impact on utility financing, therefore, may differ both over time and across regulatory jurisdictions.

This theory of regulatory influence is tested by examining several episodes in the financing experience of U.S. electric utilities from 1912 to 1979. Evidence of a regulatory effect on utility financing is found particularly for the early years of state commission regulation. Examples of an adaptive response pattern on the part of regulators, firms and consumers are also cited.

Robert A. Taggart, Jr. J.L. Kellogg Graduate School of Management Northwestern University Evanston, Illinois 60201

(312) 492-3562 


\section{Effects of Regulation on Utility Financing:}

Theory and Evidence

The influence of regulation on public utilities' capital-1abor choices has been the subject of an extensive literature, beginning with the seminal contribution of Averch and Johnson (1962). ${ }^{1}$ By comparison, regulation's influence on utility financing decisions has received relatively little attention, even though this latter issue is of interest from two standpoints. First, from the standpoint of the microeconomic theory of public policy, any regulation-induced departures from an optimal financing mix may have welfare implications for utility customers and securityholders and for the economy at large. These implications have been alluded to in policy debates, ${ }^{2}$ but have been the subject of 1ittle formal theoretical analysis. ${ }^{3}$ Second, from the standpoint of corporate finance theory, regulation may have important effects on the capital market "frictions" that are thought to determine an optimal capital structure. ${ }^{4}$ Both the tax considerations and incentive problems that influence the debt-equity mix may be perceived differently by firms subject to regulation than by those that are not. 5

The purpose of this paper is to present a theory and empirical tests of the influence of regulation on utility financing decisions. In Section I, a theory is developed incorporating the motivations of regulators, consumers and the firm's securityholders, and it is shown that regulation can affect a utility's financing mix in a variety of ways, depending on specific assumptions about the regulators' behavior and the economic environment. In particular, firms may be induced to use greater proportions of either equity 
or debt financing, depending on how hard-pressed economically are firms and consumers and on whether regulators behave in a naive or sophisticated fashion.

In Section II, selected episodes in the financing experience of U.S. electric utilities from 1912 to 1979 are analyzed. This lengthy time period encompasses a broad range of economic environments as well as the evolutionary development of regulation by state commissions, and it thus allows testing for different types of regulatory influences on utility capital structures. In the early years of state regulatory commissions, for example, it is found that firms may have been induced to use greater amounts of debt and preferred stock financing than they otherwise would have, in an attempt to influence the output prices set by the commissions. In the period from World War II to about 1970, on the other hand, it is argued that regulation probably had a more passive influence on utility financing, and in the economically-pinched. decade of the 1970's, regulation may have induced some firms to use more equity financing.

I. Regulation and Utility Financing: Theory

A. Participants in the Regulatory Process and their Motivations

The first step in analyzing regulation's influence on utility financing is to develop a model of the motivations and decisions of the various actors in the regulatory process. The set of actors in this model consists of three groups: the regulated firm and its securityholders, consumers of the firm's output, and the regulatory commissioners.

The firm produces output, $Q_{t}$, in each period, $t$, and sells this output to consumers at a price, $P_{t}$, that is set by the regulators in each period. The price is determined by the regulatory "climate," $R_{t}$, which will be explained 
in greater detail below. Price in turn determines consumers' demand, and it is assumed that the firm is obligated to produce enough output to satisfy whatever demand occurs in each period.

A possible representation of the production process is that the firm chooses a capital stock, $K$, at the beginning of the period (i.e. at time t-1) and a means for financing this capital stock. For the time being, we will confine possible financing sources to debt, D, and equity, E, so for a given capital stock the financing decision is fully specified by choosing a value of $D^{6}$. Once the capital stock and financing decisions have been made at the beginning of the period, uncertainty is resolved, and the firm must employ a variable input (fuel, say, or labor, or some fixed-proportion combination thereof) in the amount necessary to satisfy demand. 7

The one other decision variable that the firm has under its control is $1_{f}$, the amount of lobbying pressure it exerts on the regulators in an attempt to win a more favorable output price. As will be seen below, the regulatory climate, $R_{t}$, depends on the firms's lobbying effort, $1_{f t}$. Lobbying effort is assumed to be costly, however, so $1_{f t}$ also affects annual expenses.

The firm's annual operating expense, $o_{t}$, which is taken to include the cost of both the variable input and the firm's lobbying effort, depends on the quantity of output to be produced, the amount of lobbying effort, the capital stock and the financing mix at time $t-1$, as given by $D_{t-1}$. The latter variable is included because such costs as negotiating with fuel suppliers may be affected by whether or not previous financing choices have put the firm in financial difficulty.

The firm may also wish to invest at time $t$ so as to augment the capital stock available for next period's production. That is, 


$$
\mathrm{K}_{\mathrm{t}}=\mathrm{K}_{\mathrm{t}-1}+\mathrm{I}_{\mathrm{t}}
$$

where $I_{t}$ is investment at time t. $I_{t}$ is in turn determined by the firm's expected cash flows, $C_{t}^{e}$, as well as its mix of previously-issued securities, $D_{t-1}$. The financing mix is included to reflect the idea, suggested by Myers (1977), that a firm's outstanding long-term debt may affect its willingness to undertake profitable investment projects.

Putting together these several pieces, the firm's after-tax operating cash flow in period $t$ is thus given by

$$
C_{t}=\left[P_{t}\left(R_{t}\right) Q_{t}\left(P_{t}\right)-o_{t}\left(Q_{t}, 1_{f t}, K_{t-1}, D_{t-1}\right)\right](1-T)-I_{t}\left(D_{t-1}, C_{t}^{e}\right),
$$

where $T$ is the corporate tax rate.

In keeping with standard corporate finance theory, the firm is assumed to make its decisions so as to maximize the total market value, $V$, of its securities. ${ }^{8} \mathrm{~V}$ is in turn taken to depend on the firm's projected operating cash flows, as well as its financing mix. At time o, then, the firm chooses $I_{0}$ and $D_{0}$ in addition, perhaps, to a contingent plan for future investment, financing and lobbying efforts, so as to maximize $v_{0}$, where

$$
v_{0}=v_{0}(\widetilde{C}, D)
$$

and where $\tilde{C}=\left(C_{0}, \widetilde{C}_{1}, \widetilde{C}_{2}, \ldots, \widetilde{C}_{t}, \ldots.\right)$ is the vector of operating cash flows and $D=\left(D_{0}, D_{1}, \ldots, D_{t}, \ldots\right)$ is the financing mix in each period. 9

The second group of actors in the model is consumers, who simply purchase the amount they desire of the firm's output at the price set by the regulatory commission. They do not necessarily accept the regulators' pricing decisions 
passively, however, but just as the firm does, may choose to exert lobbying presures, $1_{c t}$, in each period. Both the amount of output purchased and the expense devoted to lobbying effort are assumed to be chosen by consumers so as to maximize utility.

The third group of actors is the regulatory commissioners who are charged with setting a price for the firm's output. The regulators are assumed to set this price so as to balance the conflicting interests of the firm and its customers, and thus their objective may be viewed formally as maximizing a weighted sum of consumers' and producer's surplus. It is further assumed, however, that the regulators have no precise algorithm for computing such surpluses, but rather that they are continually groping for a solution in a world of uncertainty and imperfect information.

The regulators may be aided by broad judicial guidelines, such as providing a "fair" return to capital, but the implementation of such guidelines is assumed to depend on the actual investment and financing decisions of the firm (and on how these are measured), as well as on the relative strength of the lobbying efforts by the firm and consumers. As in Joskow (1974), the commissioners may use the level of criticism and pressure from these two constituent groups as a guide to how well they are serving their judicial mandate. Prices may be altered in response to pressures from both sides in such a way as to minimize the total volume of criticism. 10 In addition, as in Owen and Braeutigam (1978), the firm may try to further influence the price-setting process by making its investment and financing decisions, and by governing the flow of information to the regulators about these decisions, in a strategic manner. ${ }^{11}$ The firn presumably has superior information about its own economic condition, and it may be able to use this advantage to alter the regulator's perception of the fair price or rate of 
return.

In summary, then, the price that is set depends on the regulatory climate, $R_{t}$, in each period, and that climate is in turn conditioned by the firm's investment and financing decisions, and by lobbying pressure from both the firm and consumers. That is,

$$
R_{t}=R_{t}\left(K_{t-1}, D_{t-1}, 1_{f t}, 1_{c t}\right) \text {. }
$$

The ultimate effect of the arguments of $R_{t}$ on the regulated price will vary with the sophistication of regulators and consumers, the regulators' weighting of firm and consumer interests, the economic environment and the costs of lobbying effort. If regulators and consumers are naive about the firm's operations, for example, the firm may be able to manipulate its decisions so as to induce the regulator to set the monopoly price, without, at the same time, arousing a countervailing lobbying effort by consumers. If the commission is sophisticated and heavily slanted toward consumer interests, on the other hand, such manipulation may be of little use to the firm. Moreover, the desire of both the firm and consumers to seek regulatory relief through lobbying effort may depend on the stringency of the overall economic environment, as well as on the costs of such efforts. ${ }^{12}$

B. How the Regulatory Environment Can Influence Utility Financing Decisions

With the motivations of these three groups in mind, we can now turn to an examination of the factors affecting utility financing. ${ }^{13}$ The optimal financing mix, for a given capital stock is that which maximizes the firm's total market value. For simplicity, attention will be confined to the 
financing decision made at $t=0$, and any effects on future financing decisions will be ignored. Substituting (4) into (2), (2) into (3), and totally differentiating ( 3 ) with respect to $D_{o}$, holding $k_{o}$ and $1_{f}$ constant, gives the first-order condition for the optimal financing mix: ${ }^{14}$

$$
\frac{d V_{o}}{d_{0}}=\frac{\partial V_{o}}{\partial D_{o}}+\frac{\partial V_{o}}{\partial C} \frac{d C}{d D_{o}}+\frac{\partial V_{o}}{\partial C} \frac{\partial C}{\partial R}\left(\frac{\partial R}{\partial D_{o}}+\frac{\partial R}{\partial I_{c}} \frac{d l_{c}}{d_{o}}\right) .
$$

The first two terms in expression (5) represent factors that would affect a firm's financing decision even in the absence of regulation. The partial derivative, $\partial \mathrm{V}_{0} / \partial \mathrm{D}_{0}$, for example, represents ways in which the firm's capital structure affects its total market value, independent of the stream of operating cash flows. These might include the tax saving from debt or additions to value stemming from signalling aspects of the firm's capital structure. 15 The second term in (5) represents any direct effects that the firm's financing decision might have on its future operating cash flows. Increased use of debt, for instance, may increase the chance that financial distress will interfere with the firm's operations in some future states of nature. Likewise, agency costs associated with the firm's external financing may manifest themselves in the form of lower operating cash flows in the future. 16

The third term in expression (5) represents ways in which the firm's financing decision may indirectly affect the cash flow stream by first influencing the regulatory climate. If the financing decision affects the regulatory climate, this may in turn affect the sequence of output prices set by the commission and hence the operating cash flows.

The first component of this term, $\left(\partial V_{0} / \partial C\right)(\partial C / \partial R)\left(\partial R / \partial D_{0}\right)$, is the direct 
effect of the firm's capital structure on the prices set by the regulators. This "price-influence effect," which has been analyzed in detail by Taggart (1981) is active primarily when regulators follow a mechanical pricing rule that depends on the firm's financing mix. One example of such a rule occurs when the regulator sets price so as to yield an allowed revenue based on allowed rates of return to the various sources of capital. If the allowed rate of return to equity is $e$, the imbedded interest cost on the firm's oustanding debt is $i$, and the regulators know the firm's demand and operating costs, the price in a given period $t$ might be set so that

$$
\left(P_{t} Q_{t}-O_{t}\right)(1-T)=i(1-T) D_{t}+e^{E_{t}}
$$

But if the allowed returns $i$ and $e$ are invariant to the firm's capital structure, as has been asserted to be the case, ${ }^{17}$ and if $e>i(1-T),(6)$ clearly indicates that the firm can win a higher price by substituting equity for debt. 18

An alternative price-influence opportunity might present itself if the firm feels that the regulators are worried about the possibility of financial distress. If it is felt that the regulators set price so as to allow the firm to maintain a particular fixed charge coverage ratio, for instance, the firm may find it worthwhile to issue more debt now than it otherwise would, thereby increasing the probability that this coverage ratio will not be maintained at the current price and thus increasing the chance for a higher output price in at least some future states of nature. ${ }^{19}$ 
The remaining term in expression (5) represents ways in which the firm's financing decision might alter consumer lobbying efforts. If the firm's attempts to influence price are successful, this may induce additional lobbying efforts by consumers, perhaps with some lag. 27

When expression (5) is considered as a whole, there appear to be two general ways in which regulation can influence utility financing decisions. First, as has been discussed in the preceding paragraphs, the firm's knowledge that its financing choice can affect the regulatory climate, and potentially the output price, may induce it to choose a different capital structure than it would have in the absence of regulation. To the extent that there is a socially optimal capital structure, this may in turn entail welfare costs. If there are real resource costs associated with financial distress, for example, and if the firm deliberately courts financial distress through additional debt issuance, in an attempt to induce the regulators to raise the output price, there is a cost imposed on society. 21

Second, the regulatory environment may affect those factors that would ordinarily determine the financing decision and may thus cause a regulated firm to choose a different capital structure from that of an otherwise equivalent unregulated firm. A case in point might be the stability of the firm's operating cash flow stream. If regulation produces a more stable environment, and if the firm's proportion of debt financing depends on the 
perceived stability of future cash flows, the regulated firm may use more debt than would an unregulated one. ${ }^{22}$ Another example is agency costs associated with external financing. Jensen and Meckling (1976) suggest, for instance, that regulation constrains managers from undertaking excessively risky projects or otherwise undermining the bondholders' position and that regulated firms are thus able to make greater use of debt financing.

At a deeper level, however, these two routes by which regulation can affect utility financing decisions stem from the same source. Whether by design or not, regulation serves as a means for transferring wealth and risks between the firm's owners and its customers. With the regulatory commission acting as mediator, each group vies with the other to ensure that the outcome of this transfer process will be favorable to itself. The firm's financing decision in a regulated environment both reflects the outcome of this process and at the same time influences that outcome.

The firm's capital structure is itself a means for wealth- and riskshifting. In an unregulated environment, such shifting typically occurs among different classes of securityholders, but under regulation the firm's customers are also involved in the process. The customers have an implicit claim on the firm in the sense that if the regulator succeeds in lowering price below the monopoly level, wealth will be shifted from the firm to the customers. The firm then has the same kind of incentives to recapture some of this wealth by undermining the customers' position that shareholders might have to undermine the bondholders' position. The possibility that the firm can gain a higher price by issuing enough debt to court financial distress 
represents an attempt by the firm to shift risk to its customers. Thus the firm's financing decision is part of a broader set of wealth-and risk-shifting activities that occur under regulation. At the same time, if regulation makes the cash flow stream more stable, thus allowing the firm to issue more debt, then the financing decision is also reflecting the effects of these shifting activites.

The basic results of this section may be summarized in terms of the model's implications for empirical observations. The primary implication is that the regulatory process should have an identifiable effect on utility financing decisions. This effect may stem from the firm's attempt to influence the regulated price through its capital structure choice or from regulation's impact on the economic environment in which the firm operates.

A second implication is that the direction of this effect will vary with both economic conditions and the behavior of the different regulatory commissions. It was seen above, for example, that the firm's attempts to influence price may lead to greater proportions of either debt or equity financing, depending on the details of the price-setting rule used by the regulators. Furthermore, regulation's effect on the firm's economic environment may vary, depending on the pressures to which the regulators have been subjected by both the firm and its customers.

Finally, the discussion of the regulators' behavior in Section I.A. suggests that the relationship between regulation and utility financing should not be immatable, but rather a process of adaptive response. If the firm is successful in influencing price through a particular financing strategy, this should reduce the welfare of consumers who will in turn exert offsetting lobbying pressure on the regulatory commission. An initially successful financing strategy may eventually be blocked, then, as the regulators adopt 
different price-setting rules or otherwise change their behavior. We might expect that financing strategies aimed at influencing price would be most successful either during the early development of regulation or immediately following the adoption of new price-setting rules, before the regulators have had a chance to develop countervailing strategies. Furthermore, the firm's desire to try to influence the price and the regulators' susceptibility to such influence should depend on the economic pressures to which both the firm and consumers are subject.

II. Regulation and Electric Utility Financing in the U.S: Empirical Evidence A. Secular Patterns in Electric Utility Finance

A rough indication of long-term trends in U.S. electric utility finance is given by the capitalization ratio plots in Figures 1 and 2 . Figure 1 traces the ratios of long-term debt, $D$, common equity, $E_{c}$ and preferred stock, $E_{p}$ to total capitalization, TC, for electric utilities. ${ }^{23}$ In Figure 2, the long-term debt ratio for electric utilities is compared with that for U.S. corporations as a whole.

In broad outline, four major eras in utility financing appear to be distinguishable. In the first two decades of the century, utilities increased their debt and preferred stock proportions rather dramatically, at the expense of common equity financing. Beginning in the 1920's and carrying through World War II, this trend was generally reversed, with the debt ratio in particular declining. The debt ratio then entered a period of increase from roughly the end of World War II to 1970. Most of this increase seems to have come at the expense of preferred stock, with the common equity series exhibiting no pronounced trend. Finally, begining around 1970 , the utility debt ratio has declined almost without interruption while the common equity and preferred 
stock ratios have tended to increase.

During some periods the financing experience of electric utilities has paralleled that of U.S. corporations as a whole, but in others it has not. As shown in Figure 2, for example, the decline in debt financing during World War II and the steady increase thereafter until 1970 occur both for utilities and the corporate sector generally. The decline in debt financing by utilities since 1970, however, seems atypical of the corporate sector as a whole. There is also fragmentary evidence, not shown in Figure 2, that long-term debt financing by the corporate sector as a whole declined between 1913 and 1922 , at the same time that utility debt financing increased dramatically. 24

In the ensuing paragraphs, the ability of the theory developed in Section I to illuminate these trends is investigated. In particular, the periods 1912-'22 and 1970-'79, in which utility financing patterns diverge from those of the corporate sector generally, are examined in detail.

B. Utility Finance in the Early Years of State Regulation The earliest electric utility companies in the U.S. were regulated by municipalities through the granting of special franchises to use the public streets. 25 Although Massachusetts established state regulation of gas utilities in 1885 , the era of state regulatory commissions is generally acknowledged to have begun in 1907 with the establishment of such commissions in New York and Wisconsin. Many other states followed suit almost immediately, with twenty-seven such commissions being established between 1907 and 1914, and this movement continued, though at a slower pace, after 1914. The theory in Secton I suggests that any effects regulation may have on utility financing are intimately associated with the price-setting process. Since formal price regulation began only with the establishment of state 
commissions, then, the years immediately following 1907 provide an experimental setting for testing the theory. In particular, the theory predicts that the financing decisions of those utilities regulated by state commissions should differ from those of utilities that are not so regulated. Without further specification of the regulatory environment, however, the theory does not predict the direction of these differences.

The first step in testing for regulatory effects is to specify an equation describing utility financing decisions in the absence of price regulation. This equation is formulated in terms of period- by-period changes in the firm's long-term debt, or

$$
\Delta D_{t}=\alpha_{1} \Delta A_{t}+\alpha_{2} D_{t-1}
$$

where $\Delta D_{t}$ and $\Delta A_{t}$ are the changes in the firm's long-term debt and total assets, respectively, occurring between time $t-1$ and time $t \cdot D_{t-1}$ is the level of the firm's long-term debt at time t-1. Equation (7) reflects the idea that the firm wishes to finance some target proportion of its additional assets in each period with long-term debt. 26 Ad justment to this target is tempered, however, by the beginning-of-period level of long-term debt, which may have been above or below target.

Equation (7) may be estimated using data from the Census of Electrical Industries. Financial data covering the early period of state regulation are available for the years 1912, 1917 and 1922 and these are reported on a statewide basis. A simple test for regulatory effects, then, entails the inclusion of dumm variables indicating whether or not the utilities in a given state were subject to state commission regulation during the period in question. Three such dumm variables are used: Rl 2 takes on a value of unity 
if the state had a commission by 1912 and zero otherwise; R17 takes on a value of unity if a state commission was established between 1912 and 1917 and zero otherwise; R22 takes on a value of unity if a state commission was established between 1917 and 1922 and zero otherwise. ${ }^{27}$ Although the theory by itself does not predict the signs of the coefficients of these dummy variables, anecdotal evidence from the period suggests that regulated utilities at this time may have emphasized securities with fixed charges (debt

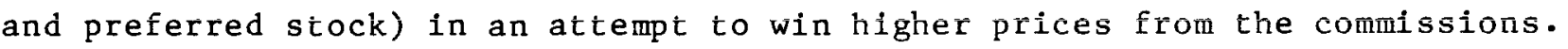
Excessive capitalizations, involving security issues far in excess of the reproduction cost of the assets were thought to be prevalent in this era. 28 Such capitalizations could be viable only if commissions granted high enough prices to support them. Firms may thus have increased their debt and preferred stock proportions in order to present the commissions with heavy schedules of fixed charges that would drive the utilities into bankruptcy if high enough prices were not granted. To test for this possibility, preferred stock is added to long-term debt in estmating equation (7), and the estimated regulatory dumy coefficients are examined for positive signs.

Given the available data, equation ( 7 ), with the three regulatory dumm variables included, could be estimated for the periods 1912 - '17 and 1917'22. The results yielded only one significantly positive coefficient for the regulatory variables, that of R22 in the perod $1917-122$. This is consistent with the notion that firms in states that formed regulatory commissions during that period may have biased their capital structures toward debt and preferrd stock in an attempt to win higher prices. Nevertheless, only five states formed commissions between 1917 and 1922, and thus this finding does not constitute overwhelming support for the presence of regulatory effects on utility financing decisions. 
When viewed in the light of Jarrell's (1978) results, however, the evidence may be stronger than it appears at first glance. Jarrell examined this same period and looked for evidence that the formation of state commissions resulted in significantly higher prices for firms in those states. He found no evidence that firms subject to state regulation enjoyed higher prices than firms with no state commission in 1912,1917 or 1922 . In fact, he found that prices of utility services were significantly lower in 1912 in those states that formed commissions by 1917 than in states that did not. By 1917, prices in the regulated states were still no higher than those in the unregulated states but the gap had been significantly narrowed. Jarrell interpreted these results as evidence that the demand by firms for state regulation was heaviest in those states where firms faced the stiffest competitive pressure prior to regulation. During the era of municipal franchising, it was common for cities to award competitive franchises, and in areas where competition was most effective, we would expect to observe lower prices, on the average, prior to regulation. If the establishment of state commissions was primarily for the benefit of firms, we would then expect to see prices in these states rising toward the levels of other states as regulation is instituted, and Jarrell argues that his results are consistent with this expectation.

A similar interpretation might be applied to utility financing during this period. If the amount of debt and preferred stock that a firm wishes to issue depends positively on both the level and stability of its cash flow stream, then a fiercely competitive environment would be less conducive to" debt and preferred stock financing. If indeed those states that formed regulatory commissions early were ones in which utility competition was heaviest to begin with, we would expect firms in these states to start out 
using lower proportions of debt and preferred stock financing. These proportions might then rise after commissions are formed, both as regulation breeds a more stable environment and as firms try to influence the commissions to grant them higher prices.

The most convenient way to check the consistency of the results here with this interpretation is to estimate equation (7) for the periods 1912 - '17 and 1917 - 22 together. Slope dumy variables can then be added to allow for changes in the coefficients, and the coefficients can be tested for significant changes between the two periods. The results of this estimation are reported in Table 1. A constant term has been added to equation (7) to allow for possible nonlinearities, and the variables other than the regulatory dummy variables have been deflated by lagged assets to correct for heteroscedasticity.

The estimated equation fits the data well, and, as might be expected, the explanatory variable that does the most work is the percentage change in assets. The coefficient of $D_{t-1} / A_{t-1}$, which was expected to be negative, is positive but not significantly so. The coefficients of primary interest are those of the regulatory dumm variables. All of these are negative (although the coefficient of $\mathrm{Rl} 2$ is not significantly negative), for the period 1912'17, suggesting that utilities in states that established regulation the earliest inftially employed lower proportions of debt and preferred stock financing. In the subsequent period, 1917- '22, however, there are strong indications that the coefficients of the regulatory dummy variables moved in a positive direction.

This evidence is consistent, then, with the notion that state regulation produced an environment more conducive to debt and preferred stock financing by electric utilities. The question that remains is whether the greater use 
of these financing sources is attributable to regulation's having produced a more stable environment or to the firms' attempts to influence regulated prices. The behavior of utilities in those states that established regulations between 1912 and 1917 suggests that the environmental effect may have been more important. This is because greater use of debt and preferred stock financing followed the establishment of regulation only with a considerable lag, and be:ause there is no evidence of any positive relation between prices in these states and the change in firms' financing patterns. Jarrel1 (1978) found, for example, that prices in those states establishing regulation between 1912 and 1917 rose most by 1917 and that part of these gains were lost by 1922. Thus the major impact of regulation on prices seems to have occurred before the impact on financing decisions, and a plausible inference is that utilities altered their financing patterns only after they saw how state regulation was affecting their environment.

For utilities in states that established regulation between 1917 and 1922, however, the evidence does not rule out a price-influence effect on financing decisions. First, the change in financing patterns in these states coincided with the establishment of regulation, and second, Jarrell's evidence indicates that price increases in these states occurred between 1917 and 1922. Since the effect of regulation on utility financing depends crucially on the behavior of individual state commissions, of course, it is not surprising that these effects may not be uniform across states and that different types of effects may have been at work in states regulated in different years. 


\section{Adaptive Responses by the Regulatory Commissions to Utility Financing}

\section{$\underline{\text { Strategies }}$}

If it is accepted that at least some utilities were indeed successful in winning higher ppices through the use of debt and preferred stock financing, the theory in Section I predicts that such success would be followed by an adaptive regulatory response. The success of such financing strategies would be detrimental to consumers who would presumably put more pressure on regulators to take counteracting measures. ${ }^{29}$ Furthermore, these consumer pressures should be stronger as consumers are more economically hard pressed.

In fact, after growing complaints about utility financial manipulations in the 1920's, state regulatory commissions began paying much more attention to utility financing in the early 1930's. Although most of the statutes establishing state regulation in the first place gave the commissions the power to review all utility securities issues, it is alleged that control over financial policy was initially quite lax. 30 In the wake of the financial difficulties experienced during the Depression, however, many commissions apparently began to take a far more active interest in financial regulation. A 1931 revision of the Wisconsin public utility law, for example, empowered the state commission to keep "all classes of capital securities in reasonable relationships to each other" and even to halt the payment of common stock dividends if these would impair the utility's financial integrity. ${ }^{31}$ In several other states, moreover, it became common to examine bond indentures closely and to "control the issuance of additional bonds under each mortgage, 
require sinking funds for most bond issues, specify provisions for depreclation and maintenance costs and limit the payments of common stock dividends. .32

The striking similarity between these statutory measures and the kinds of covenants customarily written into bond indentures, suggests that regulatory commissions became increasingly aware that utilities could follow financing strategies detrimental to consumers. ${ }^{33}$ The utilities could try to shift wealth from consumers to themselves through exactly the same strategies that an ordinary firm might use to undermine existing bondholders' positions and thus shift wealth from bondholders to shareholders. As the theory suggests, however, attempts by firms to use these strategies were apparently met by countervailing measures on the part of legislators and regulators.

\section{Utility Financing From World War II to 1970}

As Figures 1 and 2 indicate, a period of rising utility debt ratios occurred from roughly the end of World War II to about 1970. Moreover, this trend seems to parallel the financing behavior of U.S. corporations generally over the same period.

Two, possibly complementary, interpretations of this trend are consistent with the model developed in Section $I$. Both interpretations revolve around changes in the economic environment which took place during this period, creating an atmosphere more conducive to corporate debt. These changes include dramatic increases in corporate tax rates, which enhanced the tax advantage to debt, as well as perceptions that the economy was becoming more stable as memories of the Depression grew dimmer. 34

The first interpretation is based on a change in regulatory attitudes. It has been argued that in the wake of the Hope Natural Gas decision of 1944, 
regulatory commissions placed greater emphasis on the cost of capital and became increasingly aware of the possibilities of debt financing for reducing this cost. ${ }^{35}$ Regulators may thus have begun pressuring utilities to make greater use of debt financing so that the tax savings could be passed on to cons uners. ${ }^{36}$ One way in which commissions applied such pressure was by setting prices on the basis of a hypothetical capital structure, containing a larger debt proportion than the utility actually possessed. But if the regulated price is independent of the capital structure actually chosen by the utility, al1 terms in equation (5) by which the financing choice, D, affects the regulatory environment, $R$, vanish, and the utility's financing decision will be dictated by the same considerations affecting that of an unregulated firm. Thus, the same changes in tax rates and perceived stability of the economic environment that induced corporations generally to issue more debt may have had similar effects on utility financing.

The second interpretation is based on Joskow's (1974) argument that regulatory constraints may not have been binding during a significant portion of this period, particularly throughout much of the 1960's. With only minor interruptions, the trend in electric utility costs was downward from 1949 to about 1968.37 If Joskow is correct in asserting that consumers are likely to complain only about prices that are rising in nominal terms, falling costs and stable, or slightly declining, prices may have allowed utilities to reach positions during this period close to what they could have achieved in the absence of regulation. Thus utilities may have had little incentive to gear their financing decisions toward influencing prices. In the absence of such incentives, utility financing decisions would then have been based on the same considerations affecting those of corporations generally. 
E. Utility Financing in the $1970^{\prime} \mathrm{s}$

As has been pointed out in Figure 1, the long trend toward increased utility debt was reversed around 1970, and electric utilities began to make greater use of common equity and preferred stock financing. The 1970's were also inflationary years in which utilities could no longer be content with stable prices, but in which requests for price increases were met with increasing consumer resistance. Regulators thus faced growing pressure from both sides of the market, and regulatory activity, as measured by the number of rate cases, increased dramatically.

In such an environment, utilities would be expected to seek higher prices through such means as lobbying with regulators and using price-influence financing strategies. At the same time, however, consumers would be sensitive to such strategies and could be expected to mount countervailing pressures against the regulators. We might expect these strategies to be successul, then, only in jurisdictions where regulators were more favorably inclined to utility interests. Furthermore, the kinds of strategies employed might be those that are least likely to arouse consumer resistance.

One such strategy might be the one described in Section I.B., in which allowed returns to debt common equity and preferred stock are invariant to capital structure proportions, so that the firm can gain higher prices by substituting common equity and preferred stock for debt. Regulators sympathetic to the plight of the utilities might be inclined to go along with this strategy, even if they were aware that required returns fluctuate with capital structure proportions, because it would allow them to grant the utilities higher prices without increasing the allowed returns to the different sources of funds. Keeping the allowed returns the same might then 
blunt consumer resistance to these price increases.

If this strategy was indeed being used, we would expect to find firms in those states whose regulators were more favorably inclined toward the utilities using less debt during the 1970's than firms in other states. An obvious difficulty in testing this proposition, of course, is to identify the states whose commissions behaved favorably toward the utilities. This was done using a composite of five investment firms' rankings of state regulatory climates, which classified states as "very favorable," "favorable" or "unfavorable," as of 1978.38

Equation ( 7 ) was then estimated with three dumm variables ( $V, F$ and $U$ ) added to reflect the three categories of states. If the financing strategy described above was indeed in use, the coefficient of at least the " $V$ " dummy variable should be significantly negative, indicating less use of debt by utilities in very favorable states for at least some period during the $1970^{\prime}$ s. $^{39}$

The equation was estimated for three periods, 1965-'70,1970-'75 and 1975-'79. In contrast to the eariler period, described in Section II.B., data were available for individual firms in every state from Statistics of Privately Owned Electric Utilities in the United States. Data for each of the three periods were available for a total of 164 firms, and the dummy variables were keyed to the states in which the individual firms did the predominant portion of their business.

The results of this estimation are shown in Table 2 . The coefficients of the percentage change, in assets decline steadily over the three periods, indicating that target levels were declining for utilities generally. In addition, the coefficient of the lagged debt-assets ratio becomes

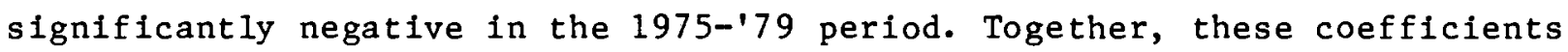


suggest that the electric utility industry in general underwent a period of financial retrenchment as the economic environment became more stringent. 40

Taken individually, none of the coefficients of the regulatory, dummy variables is significantly different from zero, and thus there is no strong evidence that the price- influence financing strategy described above was widely followed. The coefficient of the dummy variable for "very favorable" states does, however, change from positive to negative between the 1970-175 and $197.5-179$ periods, the only such coefficient to do so. 41 Moreover, the regulatory dummy variables taken as a group, while not significantly different from zero for the 1965-'70 or 1970-'75 periods, do become significant for the 1975-'7.9 period. 42 By the latter half of the 1970's, therefore, something about the various regulatory environments had changed so that this particular classification scheme took on some power to explain utility financing behavior.

Taken as a whole, then, this evidence is at least weakly consistent with the notion that utility financing decisions were influenced by regulation as the economic environment became more stringent. In addition, although financial retrenchment in the face of increased economic instability appears to be the major cause of the decline in debt financing, some firms in the "very favorable" states may have altered their financing strategies in an attempt to influence price. ${ }^{43}$

There is a variety of reasons that may explain why the evidence reported above is not stronger. One of these is that regulatory commissions may indeed adjust allowed returns for capital structure changes so that the hypothesized financing strategy would not be effective. ${ }^{44}$ In many states, in fact, consumer sensitivity to price increases may have forced the conmissions to make such adjustments. In addition, the state classification scheme used above may 
not be accurate or constant over time, and even if it is, not all firms in a given state may be in a position to employ similar financing strategies. Nevertheless, the evidence does give some suggestion of regulatory influence on utility financing decisions, and hence the precise nature of this influence may bear further investigation.

III. Conclusion

The primary argument of this paper has been that regulation influences utility financing decisions both by conditioning the economic environment in which these decisions are made and by giving firms opportunities to engage in strategic financing behavior. The channels through which this influence occurs, however, are continually changing as a result of a pattern of adaptive responses by firms, regulators and consumers. The direction of the influence on utility financing, therefore, may differ both over time and across regulatory jurisdictions.

Although the changing nature of the process makes this regulatory influence difficult to isolate at times, it does leave its traces in the data, and a review of the trends in utility financing yields illustrations of the pattern of adaptive response. While the bulk of scholarly attention has been devoted to regulation's influence on the firm's real input decisions, then, both theory and evidence suggest that the financing decision is an integral part of the interplay between utilities, regulators and consumers. 
告

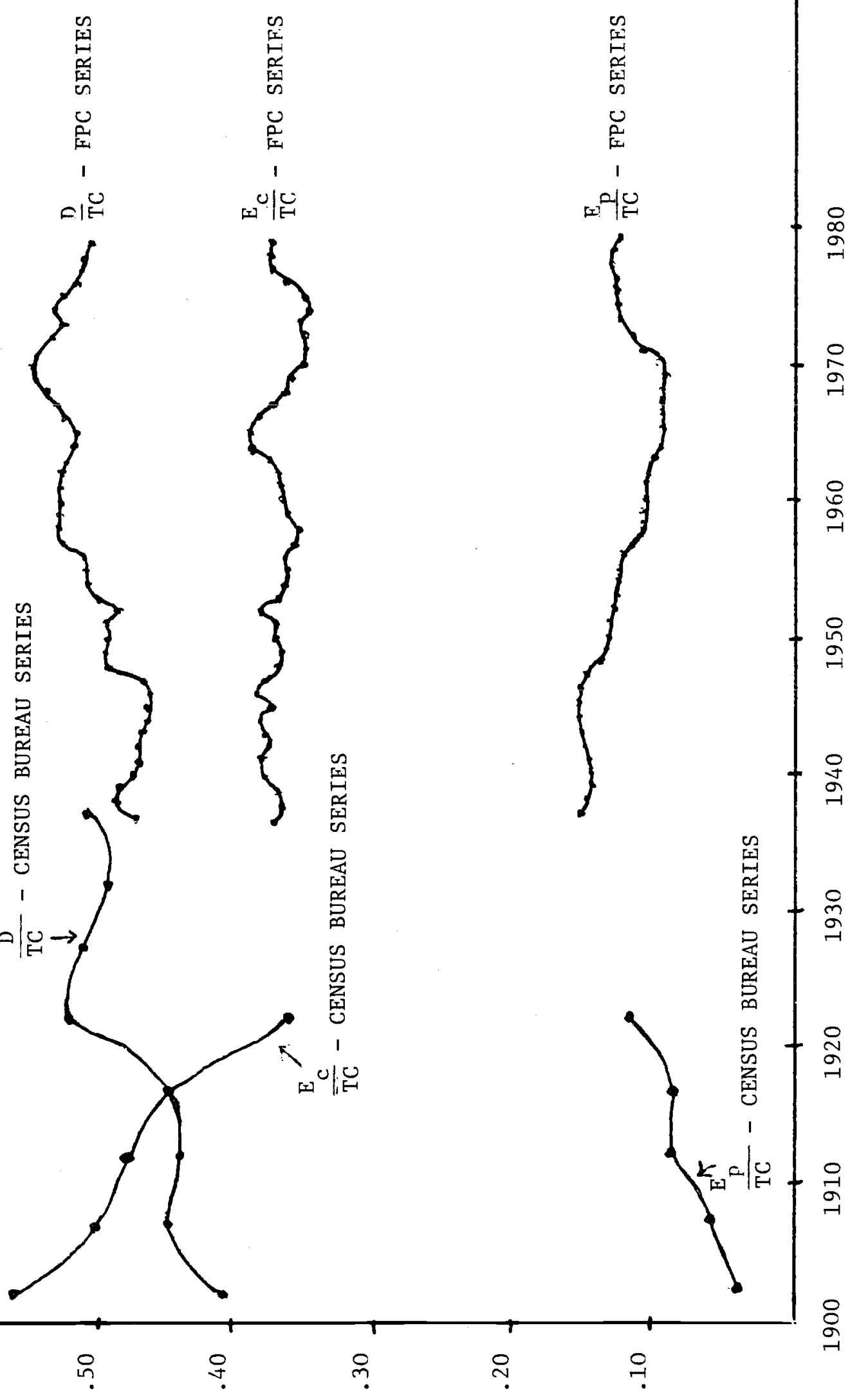




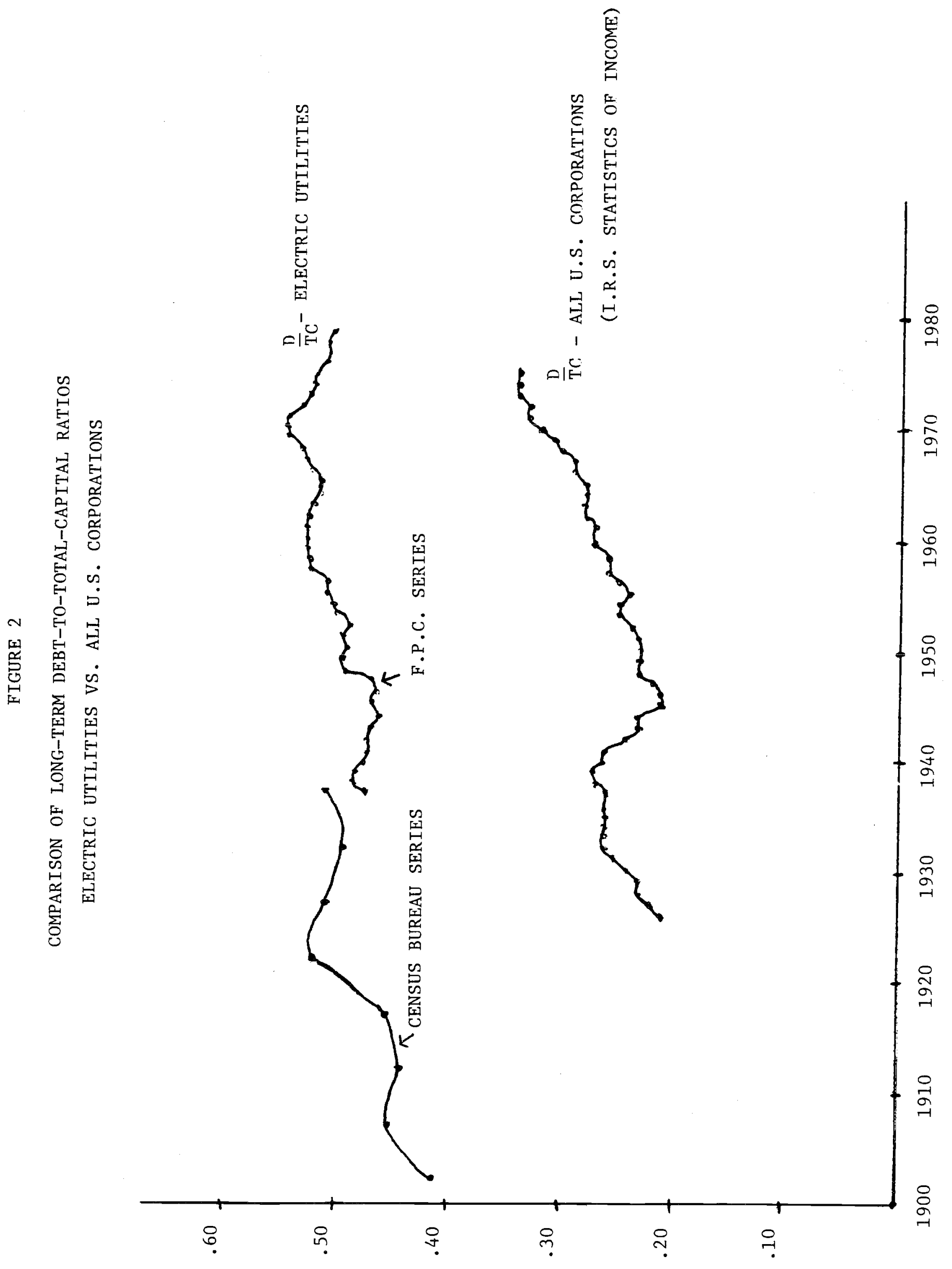


Table 1

Estimates of Equation (7), With Regulatory Dummy

Variables, for Periods 1912 -'$^{\prime}$ and 1917-'22 Combined

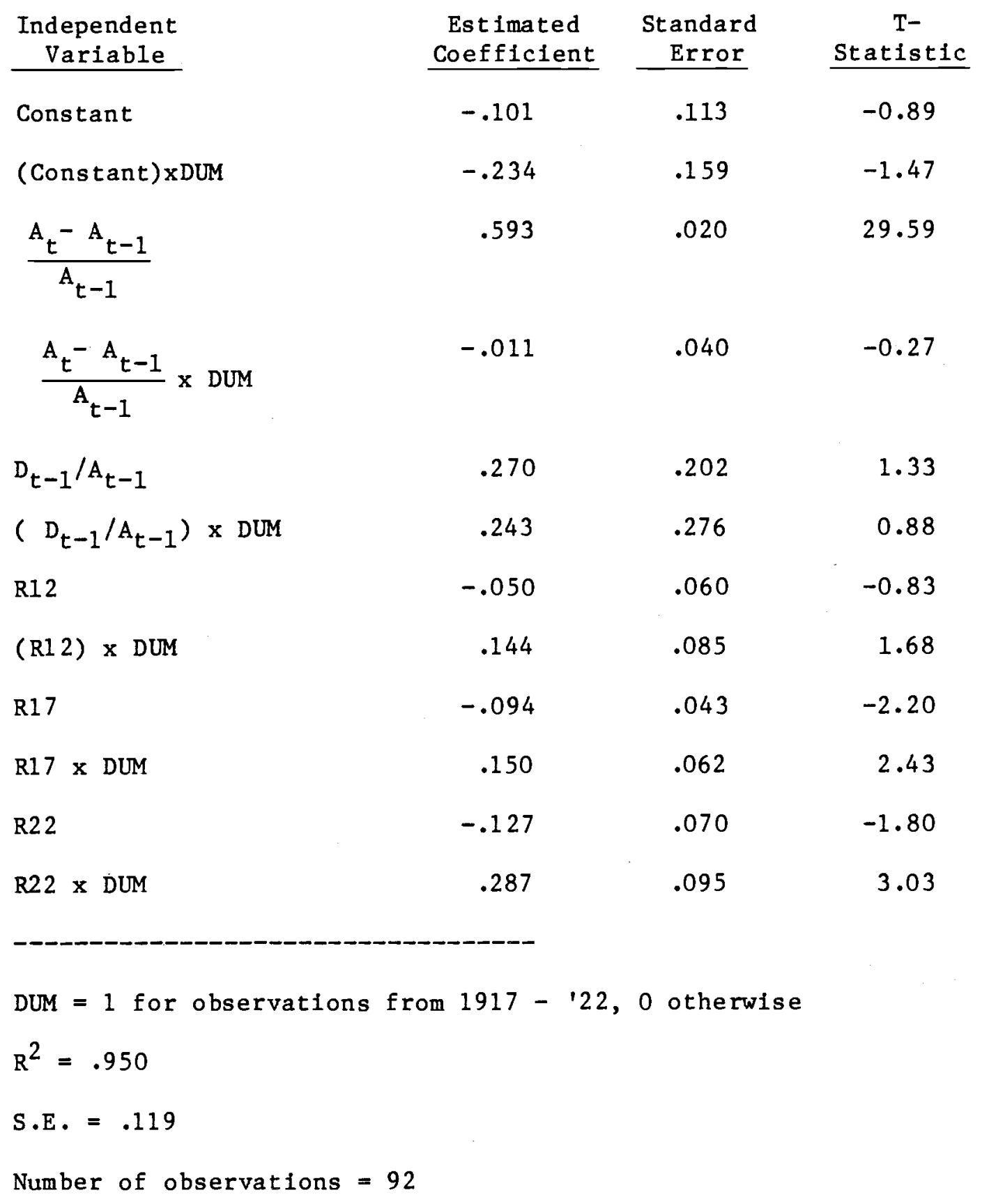


Table 2

Estimates of Equation (7), with Regulatory Dummy Variables for Periods 1965-'70, 1970-'75, 1975-'79

Independent Variables

$$
\text { Constant } \frac{A_{t}-A_{t-1}}{A_{t-1}} \quad \frac{D_{t-1}}{A_{t-1}} \quad V \quad \text { V } \quad U
$$

$1965-' 70$

$\begin{array}{lrrrrrr}\text { Estimated Coefficient } & -.032 & .552 & .045 & -.026 & -.007 & -.018 \\ \text { Standard Error } & .057 & .025 & .080 & .043 & .042 & .043 \\ \text { T-Statistic } & -0.57 & 22.35 & 0.57 & -0.60 & -0.18 & -0.43\end{array}$

$\mathrm{T}-\mathrm{Statistic}$

$\mathrm{S} \cdot \mathrm{E} \cdot \mathbf{=} .090$

\section{$1970-175$}

$\begin{array}{lrrrrrr}\text { Estimated Coefficient } & -.056 & .475 & -.032 & .008 & .007 & .031 \\ \text { Standard Error } & .058 & .019 & .081 & .044 & .043 & .044 \\ \text { T-Statistic } & -0.96 & 24.69 & -0.39 & 0.17 & 0.16 & 0.72\end{array}$

$\mathrm{T}-\mathrm{S}$ tatistic

$S \cdot E=.093$

\section{$1975-179$}

Estimated Coefficient

Standard Error

$\mathrm{T}-\mathrm{Statistic}$

$\begin{array}{rrrrrr}.080 & .437 & -.336 & -.027 & .023 & .018 \\ .045 & .018 & .067 & .036 & .035 & .035 \\ 1.79 & 23.64 & -4.98 & -0.76 & 0.68 & 0.53\end{array}$

$\mathrm{R}^{2}=.783$

S.E. $=.075$

A11 equations have 164 observations. 
Footnotes

1. See Bailey (1973) for a comprehensive survey of this literature.

2. See, for example, Weidenbaum (1975).

3. One exception is Litzenberger and Sosin (1979). This paper will be discussed in more detail below.

4. In the absence of such frictions, Modigliani and Miller (1958) and others have shown that the firm's financing choice has no effect on its optimal investment decisions or on its total market value.

5. Analyses along these lines have previously been applied to regulated financial institutions. Scott and Mayer (1971), Merton (1977) and Buser, Chen and Kane (1981), for example, discuss the incentive problems associated with deposit insurance and their effect on commercial bank financing decisions. Joskow (1973) describes the way price regulation in the property and liability insurance industry can alter firms' incentive to provide capital backing behind their policies. In the public utilities field, discussion has largely centered on the firm's perception of the tax benefits to debt in the presence of regulation. See Gordon (1967), E1ton and Gruber (1971), Gordon and McCallum (1972) and Litzenberger and Sosin (1979).

6. That is, $K_{t-1}=D_{t-1}+E_{t-1}$, where $E_{t-1}$ and $D_{t-1}$ are stated at book value (or original cost of the capital stock). For simplicity, such factors as 
depreciation and inflation will be ignored here, so there is no divergence between book value and reproduction cost.

7. Uncertainty may enter in a variety of ways. Demand may be uncertain at the time the firm chooses its capital stock, for example, in, which case the amount of the variable input necessary to meet demand is uncertain as of t-1. Alternatively, the firm may have to set its capital stock before fuel costs or wage rates prevailing at time $t$ are known. The exact source of the uncertainty is not crucial to the analysis. It is important only that the firm's stream of operating cash flows is uncertain.

8. The value-maximization assumption does mask an important underlying assumption. Conflicts of interest between both the firm's managers and its securityholders and between bondholders and shareholders are assumed to have been resolved. Although such conflicts may play a role in utility financing and investment decisions, this assumption allows the analysis to focus on conflicts between the firm, taken as a whole, and consumers and regulators.

9. The form of (3) is intended to be general, although a specific example may render it more familiar. In the Modigliani-Miller (1963), taxadjusted valuation framework, for instance, if expected operating cash flows are constant at the level $\bar{C}$ from $t=1$ to $\infty$, debt outstanding is constant at $\bar{D}$, and $\rho$ is the appropriate discount rate for $\bar{C}$ we would have

$$
\mathrm{V}=\frac{\overline{\mathrm{C}}}{\rho}+\mathrm{T} \overline{\mathrm{D}}
$$

Other, perhaps more complex, valuation expressions would also, however, be consistent with (3). 
10. Jarrell (1978) presents a formal model in which regulators maximize political support. An analogous model could be formulated here in which the regulators minimize political disfavor, as indexed by the lobbying pressures from firms and consumers.

11. An example of such behavior is provided by the Averch-Johnson (1962) model. Although the Averch-Johnson model assumes that the firm sets its own price, subject to a rate-of-return constraint, that model can nevertheless be interpreted as one in which the firm biases its investment decision in order to influence output price as set by the regulators. See Baron and Taggart (1980) for a discussion of this interpretation.

12. Joskow (1974), for instance, asserts that consumers will offer little opposition to utility profits as long as the price of service is not rising in nominal terms.

13. The framework of Section I.A. could be used to analyze other utility decisions also, but attention will be focused here on the financing decision.

14. Time subscripts have been omitted from $C, R, I_{f}$ and $I_{c}$ and these variables should thus be interpreted as vectors. $C$, for example, is the vector of cash flows from $t=0$ to $t=\infty$.

15. See Ross (1977) for a discussion of such signalling considerations.

16. See Jensen and Meckling (1976) for a discussion of these agency costs. A good case in point is the underinvestment problem described by Myers (1977).

17. See, for example, Sherman (1977).

18. Expression (6) can also be modified to include both common and preferred equity, $E_{c}$ and $E_{p}$. If $e_{c}$ and $e_{p}$ are the respective allowed returns ( $e_{p}$ 
will typically be taken as an imbedded cost), (6) becomes

$\left(P_{t} Q_{t}-O_{t}\right)(1-T)=i(1-T) D_{t}+e_{p} E_{p t}+e_{c} E_{c t} \cdot$

If $e_{p}>i(1-T)$, then, output price can also be increased by substituting preferred stock for debt.

19. A model of this type of price-influence effect is analyzed in Taggart (1981).

20. The firm's financing decisions may also indirectly affect the first-order condition for the firm's own lobbying efforts.

For example, lobbying efforts by the firm may be less productive at the margin the closer is the output price to the monopoly level. A successful effort to raise price through financing decisions, then, may decrease the marginal productivity of lobbying efforts.

21. In a related line of reasoning, Litzenberger and Sosin (1979) argue that regulators themselves induce utilities to issue more debt than they otherwise might. This increases the tax saving from debt, which can be passed on to consumers in the form of lower prices, but also imposes additional financial distress costs on society. There are no offsetting societal benefits, moreover, since the additional tax saving by the firm in effect helps to subsidize local consumers at the expense of taxpayers generally .

22. The amount of debt that is optimal may depend on the stability of the cash flow stream, for example, if the probability of incurring financial distress costs is an important consideration. Alternatively, as DeAngelo and Masulis (1980) have argued, unstable cash flows may increase the chance that some of the firm's tax shields will not be fully used and this will reduce the value of the tax saving from debt.

23. The underlying data for Figure 1 were taken from two sources. From 1902 
to 1937 , data on privately-owned electric utilities were published every five years by the U.S. Bureau of the Census in Census of Electrical Industries, Central Electric Light and Power Stations. In 1937 the Federal Power Commission (now the Federal Energy Regulatory Commission) began publishing the annual Statistics of Privately Owned Electric Utilities in the United States. The comparison figures for all U.S. Corporations in Figure 2 are from the Internal Revenue Service's Statistics of Income. All data are measured at book value. For some purposes, market value measures would be superior, but these are not readily available for the utility industry as a whole. Comparisons of financing ratios measured at estimated market value with those measured at book value for U.S. Corporations as a whole are made in Taggart (1981b). These comparisons suggest that, although there is more variation in the market value series, the two series exhibit broadly similar trends, particularly in the post-World War II period.

24. Between 1901 and 1912, for example, long-term debt issues accounted for 23 pecent of total corporate sources of funds. During the period 191322, however, this proportion fell to 12 percent. See Goldsmith (1958).

25. A good capsule review of the early history of electric utility regulation may be found in Jarrell (1978). See also Glaeser (1927) and Troxel (1947) for further detalls.

26. Similar specifications, in which firms adjust their sources of funds to target levels have generally proved useful in describing financial behavior. See Taggart (1977), for example.

27. Following the convention of Stigler and Friedland (1962), it is assumed that effective commission regulation began three years after the commission was established by law in that state. Dates on which the 
various state commissions were established are available in Stigler and Friedland.

28. See Jarrell (1979) for evidence that reported capitalizations of utilities in regulated states exceeded levels that could be attributed to their real capital stocks. See also Thompson (1932) for a somewhat more lurid rendition of the same theme. The consolidation occurring in the industry during this period provides one possible explanation for these overcapitalizations. One utility may have bought out another at a price reflecting a substantial "goodwill" value and then capitalized this goodwill in the form of securities issues. It might then hope to realize the goodwill over time by asking the commission for high enough prices to service the securities.

29. Firms themselves, of course, can also follow adaptive strategies to try to ward off pressure from consumers. It became quite common in the $1920^{\prime}$, for example, for utilities to try to sell special classes of preferred stock directly to their customers. Apart from economizing on issue costs, one of the motivations for this practice was presumably to minimize consumer pressure for rate reductions by giving them an ownership stake in the firm. See Clemens (1950), Chapter 5.

30. See Troxe1 (1947), Chapter 7, and Glaeser (1957), Chapter 7.

31. See Glaeser (1957), Chapter 7.

32. Troxel (1947), p. 160. The Securities and Exchrnge Commission also began exercising similar controls over utility holding companies under the Public Utility Holding Company Act of 1935.

33. Although Jensen and Meckling (1976) suggest that these measures economize on monitoring activities that would otherwise be undertaken by 
bondholders, then, their real purpose may be to protect consumers from price-influence financing strategies by the utilities.

34. These changes in the economic environment and their influence on the financing behavior of corporations generally, are discussed in Gordon and Malkie1 (1981).

35. See Nichols and Welch(1964). Articles also appeared during this period exhorting regulators to worry less about excessive debt, as they had done in reaction to the previous periods, and pay more attention to the costsaving benefits of debt. See Cook and Cohn (1959).

36. This interpretation has been stressed by Gordon (1967), Robichek (1978) and Litzenberger and Sosin (1979).

37. See Joskow (1974), Table 4 .

38. See Navarro (1981) for details of this ranking scheme. The classification is not exhaustive, as some states are not listed in any of the three categories.

39. In contrast to the estimation in Section II.B., preferred stock is not included as debt here.

40. It has been suggested that some utilities were prevented from issuing as much debt as they wished during this period by coverage ratio restrictions in their bond indentures. Results similar to those shown in Table 2 are obtained if the lagged interest coverage ratio is substituted for the laggged debt-assets ratio.

41. A test for the significance of this change, similar to those conducted in Section II.B., revealed that this change was not significant.

42. The F - ratios for testing whether the coefficients of the regulatory dummy variables as a group are significant are $.414, .799$ and 3.99 for 
the three periods, respectively. The latter ratio indicates significance at the $1 \%$ leve 1 .

43. Some anecdotal evidence can also be mustered in support of this contention. In a 1979 rate case in North Carolina (one of the "very favorable" states), Duke Power argued that it did not seek any increase in its $13.59 \%$ allowed return on equity, but rather that it needed higher prices so that it could actually earn the allowed return. A public witness argued that the company had increased its equity ratio since the last rate case and that the allowed return to equity should, therefore, be adjusted downward. This argument, however, was rejected by the commission. See Public Utilities Reports (1979).

44. Laber (1980), for example, rejected the hypothesis that allowed rates of return were invariant to capital structure proportions. He did, however, cite anecdotal evidence suggesting that the hypothesis may have been accurate in at least some states. 
H. Averch and L.L. Johnson, "Behavior of the Firm Under Regulatory Constraint," "American Economic Review, Vol. 52 (December 1962), pp. 1052 -69 .

E.E. Bailey, Economic Theory of Regulatory Constraint (Lexington, Mass.: Lexington Books, D.C. Heath, 1973).

D.P. Baron and R.A. Taggart, "Regulatory Pricing Procedures and Economic Incentives" in M.A. Crew, ed. Issues in Public Utility Pricing and Regulation (Lexington, Mass.: Lexington Books, D.C. Heath, 1980).

S.A. Buser, A.H. Chen and E.J. Kane, "Federal Deposit Insurance, Regulatory Policy and Optimal Bank Capital," Journal of Finance, Vol. 36 (March 1981), pp. 51-60.

E.W. Clemens, Economics and Public Utilities (New York: Appleton-CenturyCrofts, Inc., 1950).

D.C. Cook and H.B. Cohn, "Capital Structures of Electric Utilities Under the Public Utility Holding Company Act," Virginia Law Review, Vo1. 45 (October 1959), pp. 981-1006.

H. DeAngelo and R.W. Masulis, "Optimal Capital Structure Under Corporate and Personal Taxation," Journal of Financial Economics, Vol. 8 (March 1980), pp. 3-29.

E.J. Elton and M. Gruber, "Valuation and the Cost of Capital for Regulated Industries," Journal of Finance, Vo1. 26 (June 1971), pp. 661-70.

Federal Energy Regulatory Commission (formerly Federal Power Commission) Statistics of Privately Owned Electric Utilities in the United States (Washington, D.C.: U.S. Government Printing Office, annual).

M.G. Glaeser, Outlines of Public Utility Economics (New York: Macmillan, 1927). 1957). Public Utilities in American Capitalism (New York: Macmillan,

R.W. Goldsmith, Financial Intermediaries in the American Econony Since 1900 (Princeton: Princeton University Press, 1958).

M.J. Gordon, "Some Estimates of the Cost of Capital to the Electric Utility Industry, 1954-57: A Comment," American Economic Review, Vol. 57 (December 1967), pp. 1267-77.

, and J. McCallum, "Valuation and the Cost of Capital for Regulated Industries": Comment, Journal of Finance, Vol.27 (December 1972), pp. 1141-46. 
R.H. Gordon and B.G. Malkiel, "Taxation and Corporate Finance," in H. J. Aaron and J.A. Pechman, eds. How Taxes Affect Economic Behavior (Washington, D.C.: The Brookings Institution, 1981).

G.A. Jarrell, "The Demand for State Regulation of the Electric Utility Industry," Journal of Law and Economics, Vol. 21 (October 1978), pp. 269-95.

,"Pro-Producer Regulation and Accounting for Assets: the Case of Electric Utilities," Journal of Accounting and Economics. Vol. 1 (August 1979), pp. 93-116.

M.C. Jensen and W.H. Meckling, "Theory of the Firm: Managerial Behavior, Agency Costs and Ownership Structure," Journal of Financial Economics, Vol. 3 (October 1976), pp. 305-60.

P.L. Joskow, "Cartels, Competition and Regulation in the Property-Liability Insurance Industry,"Bell Journal of Economics, Vol. 4 (Autumn 1973), pp. 375-427.

"Inflation and Environmental Concern: Structural Change in the Process of Public Utility Price Regulation," Journal of Law and Economics, Vol. 17 (October 1974), pp. 291-327.

G. Laber, "Capital Structure Decisions of Regulated Firms," unpublished paper, University of Vermont, September 1980.

R.H. Litzenberger and H.B. Sosin, "A comparison of Capital Structure Decisions of Regulated and Non-Regulated Firms," Financial Management, Vol. 8 (Autumn 1979), pp. 17-21.

R.C. Merton, "An Analytic Derivation of the Cost of Deposit Insurance Loan Guarantees: An Application of Modern Option Pricing Theory," Journal of Banking and Finance, Vol. 1 (June 1977), pp. 3-11.

F. Modigliani and M.H. Miller, "The Cost of Capital, Corporation Finance and the Theory of Investment," American Economic Review, Vol. 48 (June 1958), pp. 261-97.

, "Corporate Income Taxes and the Cost of Capital-A Correction" American Economic Review, Vol. 53 (June 1963), pp. 433-43.

S.C. Myers, "Determinants of Corporate Borrowing," Journal of Financial Economics, Vol. 5 (November 1977), pp. 147-75.

P. Navarro, "Electric Utility Regulation and National Energy Policy," Regulation, Vol. 5 (January/February 1981), pp. 20-27.

E. Nichols and F.X. Welch Ruling Principles of Utility Regulation, Rate of Return Supplement A (Washington, D.C.: Public Utilities Reports, Inc., 1964).

B.M. Owen and R. Braeutigam, The Regulation Game: Strategic Use of the Administrative Process (Cambridge, Mass: Ballinger, 1978). 
Public Utilities Reports, 4th Series, Vo1. 26 (Washington, D.C.: Public Utilities Reports, Inc., 1979).

A.A. Robichek, "Regulation and Modern Finance Theory," Journal of Finance, Vo1. 33 (June 1978), pp. 693-705.

S.A. Ross, "The Determination of Financial Structure: The Incentive Signalling Approach," Bell Journal of Economics, Vol. 8 (Spring 1977), pp. 23-40.

K.E. Scott and T. Mayer, "Risk and Regulation in Banking: Some Proposals for Deposit Insurance Reform," Stanford Law Review, Vol. 23 (May 1971), pp. 857-902.

R. Sherman, "Financial Aspects of Rate-of-Return Regulation," Southern Economic Journa1, Vo1. 44 (October 1977), pp. 240-248.

G.J. Stigler and C. Friedland, "What Can Regulators Regulate? The Case of Electricity," Journal of Law and Economics, Vol.5 (October 1962), pp. $1-16$.

R.A. Taggart, "A Mode1 of Corporate Financing Decisions," Journal of Finance, Vo1. 32 (December 1977), pp. 1467-84.

, "Rate-of-Return Regulation and Utility Capital Structure Decisions," Journa1 of Finance, Vo1. 36 (May 1981), pp. 383-93.

, "Secular Patterns in Corporate Finance," NBER Working Paper No. 810, Cambridge, Mass., December 1981.

C.D. Thompson, Confessions of the Power Trust (New York: E.P. Dutton \& Company, 1932).

E. Troxe1, Economics of Public Utilities (New York: Rinehart \& Company, 1947).

U.S. Bureau of the Census, Census of Electrical Industries, Central Electric Light and Power Stations(Washington, D.C.: U.S. Government Printing office, 1912, 1917, 1922).

U.S. Internal Revenue Service, Statistics of Income (Washington, D.C.: U.S. Government Printing of fice, annua1).

M.L. Weidenbaum, Financing the Electric Utility Industry (St. Louis: Center for the Study of American Business, Washington University, 1975). 